\title{
Recent Advances in HIV Associated Renal Disease
}

\section{Xuezhu Li' and Shougang Zhuang ${ }^{1,2 *}$}

${ }^{1}$ Department of Nephrology, Shanghai East Hospital, Tongji University School of Medicine, Shanghai, China

${ }^{2}$ Department of Medicine, Rhode Island Hospital and Alpert Medical School of Brown University, Providence, USA

\begin{abstract}
Renal disease is becoming an important cause of morbidity and mortality in HIV-affected individuals, as the Highly Active Anti-retroviral Therapy (HAART) has been widely used in HIV-positive patients. HIV infection can cause severe kidney disease directly, including acute kidney injuries, thrombotic micro-angiopathies, HIV-associated Nephropathy (HIVAN), and HIV Immune Complex Kidney Disease (HIVICK) as well as progress to Chronic Kidney Disease (CKD).In this review, we analyze the recent advances in renal complications associated with HIV infection.
\end{abstract}

Keywords: Human immunodeficiency virus; HIV-associated nephropathy; HIV immune complex kidney disease; HIV associated acute kidney injury

\section{Introduction}

Renal disease is becoming an important cause of morbidity and mortality in populations with Human Immunodeficiency Virus (HIV) infection, as HIV infection has a tendency to progress to a chronic disease [1] .With the prevalence of HIV increasing, the size of HIVinfected population and the longevity of HIV-affected patients are increasing due to the Highly Active Anti-retroviral therapy (HAART). HIV infectioncan cause severe kidney disease directly, including acute kidney injuries, thrombotic micro-angiopathies, HIV-associated Nephropathy (HIVAN), and HIV Immune Complex Kidney Disease (HIVICK). Previously, collapsing Focal Segmental Glomerulosclerosis (FSGS) were thought to be prevalent in HIV-infected patients, but it has been currently appreciated that kidney disease encompassed the entire spectrum of renal pathologies in the HIV population. Rao et al., divided the HIV-1-associated renal parenchymal diseases into four groups [2]: (1) acute tubular dysfunction with electrolytes abnormalities and/ or renal failure caused by infections and nephrotoxic drugs; (2) HIV glomerulophaties related to immunological abnormalities (3) ; HIVassociated thrombotic micro-angiopathies; and (4) HIVAN. In HIVassociated renal disease patients have a higher risk for End Stage Renal Disease(ESRD) than general population. In this review, we highlight the recent advances on the renal complications associated with HIV infection.

\section{HIV-associated Nephropathy (HIVAN)}

HIVAN, first described in 1984, is the most prevalent form of HIVassociated kidney disease. It is a kidney syndrome in HIV-1 seropositive patients, characterized by collapsing focal sclerosing glomerulopathy, heavy proteinuria, kidney dysfunction and rapid progression to kidney failures, which occurs in $2-10 \%$ of HIV-infected patients, most often affecting individuals of African descent [3,4] . Histopathological findings include collapsing glomerulopathy, global or focal glomerulosclerosis, icrocystic transformation of renal tubules, interstitial inflammation and hyperplasia of podocytes [5].The risk of kidney disease progression in HIV positive black patients is increased [6-8]. In recent years there have been important advances in understanding the pathogenesis of the disease with some APOL1 polymorphisms described in association with an increased risk for HIVAN and progression to ESRD [9-11].

APOL1 is expressed in podocytes, and the relevance of APOL1 risk alleles in patients of African descent with HIVAN is high, implicating potential podocyte effects $[12,13]$. And recent genetic studies implicate the APOL1 G1 and G2 alleles to account in part for this excess of risk $[9,11,14]$. In addition, AT(1)R and AT(2)R have been reported to play an important role in the progression of HIVAN [15]. The beneficial effects of HAART on HIVAN have been supported by renal biopsy, showing adramatic improvement of renal histological findings of patients receiving anti-retrovirals [16,17]. Data from several Randomized Controlled Trials (RCT) studies suggest steroids and angiotensin-converting enzyme inhibitors appear to improve kidney function in patients with HIVAN[18].Early recognition of the disease is crucial to start Combination Antiretroviral Therapy (cART) and renin-angiotensin system blockers before irreversible renal injury[19].

\section{HIV Immune Complex Kidney Disease (HIVICK)}

HIV Immune Complex Kidney Disease (HIVICK) is reported in $21 \%$ of hospitalized patients with advanced kidney dysfunction [20]. The racial predilection for HIVICK is conflicting. An early study showed very few black HIV-positive patients with HIVICK based on the results of renal biopsy[21] ; another study indicated, $80 \%$ of HIVinfected patients being white [22].

However, a recent study of 751 HIV-infected patients in United States showed that HIVICK patients were predominantly African American (92\%), HIVICK patients were more likely to have HIV RNA $>400$ copies $/ \mathrm{ml}$, diabetes, and hypertension. Comparedwith HIVAN, patientswith HIVICK had more antiretroviral the rapy exposure, lower HIV viral loads, and higher CD4 and estimated GFR. ESRD incidence is lower in HIVICK patients compared with those with HIVAN.

Unlike HIVAN, cART use was not associated with the incidence of ESRD in HIVICK [23]. HIV viral replication or immune responses to viral proteins may be essential to trigger HIVICK, and the patients associated with hypertension and diabetes should receive a kidney biopsy. In a cohort of African-American patients with biopsy-proven non-HIVAN renal pathology, $76 \%$ of patients carrying two APOL1 risk

*Corresponding author: Shougang Zhuang, Department of Medicine, Rhode Island Hospital and Alpert Medical School of Brown University, Providence, RI 02903, USA, Tel: 401-444-6867; Fax: 40-444-6849; E-mail: szhuang@lifespan.org

Received January 29, 2014; Accepted January 31, 2014; Published February 03, 2014

Citation: Li X, Zhuang S (2014) Recent Advances in HIV Associated Renal Disease. J Trop Dis 2: e107. doi: 10.4172/2329-891X.1000e107

Copyright: (C) $2014 \mathrm{Li} \mathrm{X}$, et al. This is an open-access article distributed under the terms of the Creative Commons Attribution License, which permits unrestricted use, distribution, and reproduction in any medium, provided the original author and source are credited. 
alleles had FSGS. In contrast, immune complex GN was found more often on renal biopsy in patients with only one or no APOL1 risk allele (47\% and $40 \%$, respectively) $[9,24]$.

\section{HIV Associated Acute Renal Injury (AKI)}

ARF is a clinical syndrome defined as an abrupt decrease in GFR over days to weeks with an increase in serum creatinine level to values $>1.5 \mathrm{mg} / \mathrm{dl}$ or $>1.3$ times the laboratory upper limit of normal), which returns to baseline values within 3 months [25]. AKI is more common in HIV-infected personsthan in the general population.Its presence in HIV infected patients is a risk factor for poor clinical outcomes, and results in lengthened time of hospitalization and a high rate of mortality. This is because that AKI is associated with an increased risk of End Stage Renal Disease (ESRD), cardiovascular disease, heart failure, and death [26]. Hospitalizations of HIV-infected patients that were complicated by AKI were also complicated by much higher in-hospital mortality (27\%) than seen in admissions of HIV-infected patients without AKI (4.5\%) [27].

On the other hand, some risk factors also contribute to the development of AKI after HIV-infection. These factors include preexisting Chronic Kidney Disease (CKD), advanced HIV infection (low CD4 + cell count and HIV viral load), HCV co infection, and antiretroviral drugs toxicity, low serum albumin $(<3.7 \mathrm{mg} / \mathrm{dl})$, low body mass index $\left(<18.5 \mathrm{~kg} / \mathrm{m}^{2}\right)$, black race, hypertension, diabetes, cardiovascular disease, hypomagnesemia, male gender and older age [28-30].

\section{Diffuse Infiltrative Lymphocytosis Syndrome (DILS)}

DILS was first reported in 1989 [31]. It is a rare complication of HIV attributed to an antigen- (viral load) driven response of expanded oligoclonal CD8+ lymphocytosis, with consequent organ infiltration that is principally manifested by parotid gland enlargement, sicca syndrome-like symptoms and life-threatening pulmonary infiltration. Renal involvement is characterized by acute tubulointerstitial nephritis with dense cellular infiltrates consisting of lymphocytes, monocytes and plasma cells[32,33].

\section{Treatment of HIV Associated Renal Disease}

Newly introduced Highly Active Anti-retroviral Therapy (HAART) has significantly reduced the incidence of HIVAN in the recent years. The HAART has been found to retard and revert the progression of renal insufficiency towards ESRD, and to increase survival of the patient. A recent large cohort study of 20,132 patients in United Kingdom showed that decreased eGFR of HIV positive patients at baseline is an independent risk factor for all-cause mortality and progression to stages 4-5 CKD, and black HIV-positive patients with eGFR of 30-59 $\mathrm{mL} / \mathrm{min} / 1.73 \mathrm{~m}^{2}$ and white/other HIV-positive patients with eGFR of $30-44 \mathrm{~mL} / \mathrm{min} / 1.73 \mathrm{~m} 2$ were at high risk of kidney disease progression, their eGFR should be monitored closely during clinical follow-up [34].

Kidney Transplantation $(\mathrm{KT})$ is an established treatment for ESRD in general population. Recent data have confirmed that KT is increasingly offered to ESRD patients with well-controlled HIV infection. A cohort study showed that KT in HIV-positive patients. In $35 \mathrm{HIV}$-positive KT recipients, the median CD4 cell count was 366, all had undetectable HIV RNA levels at kidney transplantation, and $44 \%$ received a kidney from a live donor. Patient survival at 1 and 3 years was $91.3 \%$, and graft survival rate was $84.7 \%$, but the cumulative incidence of acute rejection was high (48\%) [35].

\section{Conclusion}

Renal disease is an increasing cause of morbidity and mortality in HIV-positive patients. Kidney disease encompassed the entire spectrum of renal pathologies in the HIV population. The close monitoring of proteinuria, renal function and the renal biopsy is important in HIVinfected patients.Till now, there is no special therapy for treatment of HIV-associated renal diseases, and however, cART and HAART have beneficial effects on patients with those diseases. In addition, application of angiotensin-converting enzyme inhibitors also improves kidney function in patients with HIVAN.

\section{References}

1. Perazella MA (2000) Acute renal failure in HIV-infected patients: a brief review of common causes. Am J Med Sci 319: 385-391.

2. Rao TK (2001) Human immunodeficiency virus infection and renal failure. Infect Dis Clin North Am 15: 833-850.

3. Rao TK, Filippone EJ, Nicastri AD, Landesman SH, Frank E, et al. (1984) Associated focal and segmental glomerulosclerosis in the acquired immunodeficiency syndrome. N Engl J Med 310: 669-673.

4. Lucas GM, Eustace JA, Sozio S, Mentari EK, Appiah KA, et al. (2004) Highly active antiretroviral therapy and the incidence of HIV-1-associated nephropathy: a 12-year cohort study. AIDS 18: 541-546.

5. Ray PE (2009) Taking a hard look at the pathogenesis of childhood HIVassociated nephropathy. PediatrNephrol 24: 2109-2119.

6. Choi Al, Rodriguez RA, Bacchetti P, Bertenthal D, Volberding PA, et al. (2007) Racial differences in end-stage renal disease rates in HIV infection versus diabetes. J Am SocNephrol 18: 2968-2974.

7. Lucas GM, Lau B, Atta MG, Fine DM, Keruly J, et al. (2008) Chronic kidney disease incidence, and progression to end-stage renal disease, in HIV-infected individuals: a tale of two races. J Infect Dis 197: 1548-1557.

8. Lucas GM, Clarke W, Kagaayi J, Atta MG, Fine DM, et al. (2010) Decreased kidney function in a community-based cohort of HIV-Infected and HIV-negative individuals in Rakai, Uganda. J Acquir Immune DeficSyndr 55: 491-494.

9. Fine DM, Wasser WG, Estrella MM, Atta MG, Kuperman M, et al. (2012) APOL1 risk variants predict histopathology and progression to ESRD in HIV-related kidney disease. J Am SocNephrol 23: 343-350.

10. Chen P, Chen BK, Mosoian A, Hays T, Ross MJ, et al. (2011) Virological synapses allow HIV-1 uptake and gene expression in renal tubular epithelial cells. J Am SocNephrol 22: 496-507.

11. Kopp JB, Nelson GW, Sampath K, Johnson RC, Genovese G, et al. (2011) APOL1 genetic variants in focal segmental glomerulosclerosis and HIVassociated nephropathy. J Am SocNephrol 22: 2129-37.

12. Papeta N, Sterken R, Kiryluk K, Kalyesubula R, Gharavi AG (2011) The molecular pathogenesis of HIV-1 associated nephropathy: recent advances. J Mol Med (Berl) 89: 429-436.

13. D’Agati VD (2012) Pathobiology of focal segmental glomerulosclerosis: new developments. CurrOpinNephrolHypertens 21: 243-250.

14. Papeta N, Kiryluk K, Patel A, Sterken R, Kacak N, et al. (2011) APOL1 variants increase risk for FSGS and HIVAN but not IgA nephropathy. J Am SocNephrol 22: 1991-1996.

15. Salhan D, Sagar A, Kumar D, Rattanavich R, Rai P, et al. (2012) HIV-associated nephropathy: role of AT2R. Cell Signal 24: 734-741.

16. Winston JA, Bruggeman LA, Ross MD, Jacobson J, Ross L, et al. (2001) Nephropathy and establishment of a renal reservoir of HIV type 1 during primary infection. N Engl J Med 344: 1979-1984.

17. Atta MG, Gallant JE, Rahman MH, Nagajothi N, Racusen LC, et al. (2006) Antiretroviral therapy in the treatment of HIV-associated nephropathy. Nephrol Dial Transplant 21: 2809-2813.

18. Yahaya I, Uthman OA, Uthman MM (2013) Interventions for HIV-associated nephropathy. Cochrane Database Syst Rev 1: CD007183.

19. Atta MG (2010) Diagnosis and natural history of HIV-associated nephropathy Adv Chronic Kidney Dis 17: 52-58. 
20. Gerntholtz TE, Goetsch SJ, Katz I (2006) HIV-related nephropathy: a South African perspective. Kidney Int 69: 1885-1891.

21. Nochy D, Glotz D, Dosquet P, Pruna A, Guettier C, et al. (1993) Renal disease associated with HIV infection: a multicentric study of 60 patients from Paris hospitals. Nephrol Dial Transplant 8: 11-19.

22. Boissier F, Khalil A, Chalumeau-Lemoine L, Lescure FX, Parrot A (2012) Rash diagnosis of blood expectoration. Lancet 379: 1170.

23. Foy MC, Estrella MM, Lucas GM, Tahir F, Fine DM, et al. (2013) Comparison of risk factors and outcomes in HIV immune complex kidney disease and HIVassociated nephropathy. Clin J Am SocNephrol 8: 1524-1532.

24. Atta MG, Estrella MM, Kuperman M, Foy MC, Fine DM, et al. (2012) HIVassociated nephropathy patients with and without apolipoprotein L1 gene variants have similar clinical and pathological characteristics. Kidney Int 82 : 338-43.

25. Mehta RL, Kellum JA, Shah SV, Molitoris BA, Ronco C, et al. (2007) Acute Kidney Injury Network: report of an initiative to improve outcomes in acute kidney injury. Crit Care 11: R31.

26. Choi Al, Li Y, Parikh C, Volberding PA, Shlipak MG (2010) Long-term clinical consequences of acute kidney injury in the HIV-infected. Kidney Int 78: 478-485.

27. Lopes JA, Melo MJ, Viegas A, Raimundo M, Câmara I, et al. (2011) Acute kidney injury in hospitalized HIV-infected patients: a cohort analysis. Nephrol Dial Transplant 26: 3888-3894.
28. Wyatt CM, Arons RR, Klotman PE, Klotman ME (2006) Acute renal failure in hospitalized patients with HIV: risk factors and impact on in-hospital mortality. AIDS 20: 561-565

29. Li Y, Shlipak MG, Grunfeld C, Choi Al (2012) Incidence and risk factors for acute kidney injury in HIV Infection. Am J Nephrol 35: 327-334.

30. Ibrahim F, Naftalin C, Cheserem E, Roe J, Campbell LJ, et al. (2010) Immunodeficiency and renal impairment are risk factors for HIV-associated acute renal failure. AIDS 24: 2239-2244.

31. Itescu S, Brancato LJ, Winchester R (1989) Asicca syndrome in HIV infection: association with HLA-DR5 and CD8 lymphocytosis. Lancet 2: 466-468.

32. Izzedine H, Brocheriou I, Valantin MA, Camous L, Bourry E, et al. (2008) A case of acute renal failure associated with diffuse infiltrative lymphocytosis syndrome. Nat Clin Pract Nephrol 4: 110-114.

33. Zafrani L, Coppo P, Dettwiler S, Molinier-Frenkel V, AgbalikaF,et al. (2007) Nephropathy associated with the diffuse infiltrative lymphocytosis syndrome. Kidney Int 72: 219-224.

34. Ibrahim F, Hamzah L, Jones R, Nitsch D, Sabin C, et al. (2012) Baseline kidney function as predictor of mortality and kidney disease progression in HIV-positive patients. Am J Kidney Dis 60: 539-547.

35. Gathogo EN, Hamzah L, Hilton R, Marshall N, Ashley C, et al. (2014) Kidney transplantation in HIV-positive adults: the UK experience. Int J STD AIDS 25 57-66. 